\title{
Genetic Analysis of Growth and Susceptibility to Bacterial Wilt (Ralstonia solanacearum) in Eucalyptus by Interspecific Factorial Crossing
}

\author{
By S. GAN ${ }^{1}$, M. LI, F. LI, K. Wu, J. Wu and J. BAI
}

Research Institute of Tropical Forestry, Chinese Academy of Forestry, Longdong, Guangzhou 510520, People's Republic of China

(Received 21 ${ }^{\text {st }}$ October 2004)

\begin{abstract}
Summary
Factorial mating crosses of Eucalyptus urophylla $\times$ E. tereticornis $(3 \times 5), E$. urophylla $\times E$. camaldulensis $(3 \times 3)$ and $E$. urophylla $\times$ E. exserta $(3 \times 3)$ were used for genetic analysis of growth traits and susceptibility to bacterial wilt (Ralstonia solanacearum). Genetic effects including female, male and female $x$ male interaction were examined for height $(\mathrm{H})$ and diameter at breast height (DBH) at age five as well as final bacterial wilt index (BWI) in both nursery inoculation and field assessment by five years of age. Female, male and female $x$ male variances appeared to have a significant role in growth traits $\mathrm{H}$ and $\mathrm{DBH}$ though their magnitude varied for the factorials studied. For the trait BWI additive (male) and dominant (female $x$ male) effects were both involved in the genetics of bacterial wilt susceptibility, and additive was the major. Estimates of narrow-sense heritability $\left(h^{2}\right)$ for $\mathrm{H}, \mathrm{DBH}$ and $\mathrm{BWI}$ ranged from $0.11 \pm 0.06$ to $0.70 \pm 0.09$, varying with either trait or factorial. Growth traits $(\mathrm{H}$ and $\mathrm{DBH})$ had low and non-significant phenotypic and genetic correlations with BWI in all the three factorials, ranging from $-0.10 \pm 0.08$ to $0.17 \pm 0.14$ in coefficient of correlation. This indicates that it may be possible to select superior trees with both fast growth and high resistance to bacterial wilt in eucalypt hybrid populations in operational breeding programs.
\end{abstract}

Key words: Eucalyptus, growth, bacterial wilt (Ralstonia solanacearum), genetic parameters.

\section{Introduction}

Eucalyptus species are important for commercial plantation forestry both in China and internationally. Genetic parameters are backbone for designing optimal breeding strategy in tree improvement programs. Up to date genetic parameters have been reported for a number of Eucalyptus species in such traits as growth, wood properties and insect resistance (BOUvET and Vigneron, 1995, 1996; HARdNer and PotTs, 1995; Hodge et al., 1996; ARAúJo et al., 1996; Grevaves et al., 1997; SoRIA and BorralHo, 1997; WeI and BorRalHo, 1998; Osorio et al., 2001; JORDAN et al., 2002; JoNES et al., 2002; LOPEZ et al., 2003). However, little information was available on the genetic structure of disease susceptibility or resistance in the genus. In addition, there were few reports comparing genetic parameters over different interspecific hybrid populations and/or within populations of interspecific hybrids in Eucalyptus. Most studies reported to date have used half- and/or full-sib families of pure species.

Bacterial wilt caused by Ralstonia solanacearum (synonym Pseudomonas solanacearum E. F. Smith) (YABUUCHI et al., 1995) is one of the most significant, widespread and lethal diseases of plants in tropical and subtropical countries (BUDDENHAGEN, 1964). The disease was not observed in eucalypt plantations until 1980s when infection cases were found in China (CHAO, 1982) and Brazil (SUdo et al., 1983). There have been

\footnotetext{
1) Corresponding author: Telephone: +8620 87032402,

Fax: +86 2087031622 , E-mail: smggan@pub.guangzhou.gud.cn
}

thereafter a number of reports on its occurrence on eucalypts in Australia, Venezuela, South Africa and Uganda (CounTinHo et al., 2000; Roux et al., 2001). In China, yield losses of 20-60\% have been observed in stands planted with susceptible clones. The infection of the bacterium is constraining further expansion of eucalypt plantation worldwide. Few measures have so far proved adequate control of the disease, and growing resistant varieties might provide a partial solution (SATHYANARAYANA and ANAND, 1993). In Eucalyptus screening for resistance to bacterial wilt has been conducted in a range of pure species (Wu and LiANG, 1988a; DiAnese et al., 1990), hybrids (GAN et al., 1998) and clones (CounTINHO et al., 2000). To our knowledge, however, no studies have been carried out to estimate the genetic variation and genetic parameters of bacterial wilt susceptibility in Eucalyptus.

In this study we present genetic analysis of height $(\mathrm{H})$, diameter at breast-height (DBH) and bacterial wilt index (BWI) in Eucalyptus using three factorial mating hybrid populations. The maternal species is $E$. urophylla, and the paternal species include $E$. tereticornis, $E$. camaldulensis and $E$. exserta. The objectives are to examine the genetic variation and estimate the genetic parameters in growth traits and bacterial wilt susceptibility in eucalypts.

\section{Materials and Methods \\ Plant material and mating design}

During 1990-1993 three maternal trees of E. urophylla were control pollinated with five paternal trees of $E$. tereticornis and three paternal trees of each of $E$. camaldulensis and $E$. exserta in a factorial mating design (Table 1). All the parents were raised from randomly selected seedlings in earlier provenance trials in mid-1980s. Unfortunately, a few of crosses were missed due to some reasons in hybridization and seedling rais-

Table 1. - Mating designs for the three interspecific factorials used in this study.

\begin{tabular}{ccccc}
\hline \multirow{2}{*}{ Factorial } & Male parent & \multicolumn{3}{c}{ Female parent } \\
\cline { 3 - 5 } & & E. urophylla 9001 & E. urophylla 3138 & E. urophylla 3134 \\
\hline I & E. tereticornis 6001 & $\times$ & $\times$ & \\
& E. tereticornis 4301 & $\times$ & $\times$ & \\
E. tereticornis 1801 & $\times$ & $\times$ & $\times$ \\
& E. tereticornis 4403 & $\times$ & $\times$ & $\times$ \\
& E. tereticornis 2001 & & $\times$ & $\times$ \\
II & E. camaldulensis 3802 & $\times$ & $\times$ & $\times$ \\
& E. camaldulensis 0603 & $\times$ & $\times$ & $\times$ \\
& E. camaldulensis 1503 & $\times$ & $\times$ & $\times$ \\
III & E. exserta 9101 & $\times$ & $\times$ & $\times$ \\
& E. exserta 9201 & $\times$ & $\times$ & \\
E. exserta 9001 & & & & $\times$ \\
\hline
\end{tabular}


ing procedures, and the final number of crosses available for experiment was eleven, eight and eight for $E$. urophylla $\times E$. tereticornis (Factorial I), E. urophylla $\times$ E. camaldulensis (Factorial II) and E. urophylla $\times$ E. exserta (Factorial III), respectively, with each parent representing at least two crosses (Table 1).

In May 199435 grains of seed of each cross and each maternal open-pollinated family were sown into heat-sterilized medium (20\% vermiculite, $79 \%$ soil and $1 \%$ compound fertilizer) contained in a $10 \times 14 \times 4 \mathrm{~cm}$ plastic tray in greenhouse. After a month 25-30 seedlings per entry were transplanted into 10cm-diameter polyethylene bags in nursery.

\section{Nursery inoculation and symptom assessment}

A strain of $R$. solanacearum was isolated from a diseased tree in an E. urophylla plantation in Xinhui County, Guangdong Province, China, and its virulence was tested both on the tetrazolium chloride (TZC) medium (KELMAN, 1954) and through an inoculation procedure (WU and LIANG, 1988b). A virulent colony was re-streaked on the same medium without TZC and then cultured for 48 hours at $30^{\circ} \mathrm{C}$, and cells were then harvested by flooding the plates with sterilized distilled water. The concentration of the inoculum suspension was adjusted to $1.5 \times 10^{9}$ cells $/ \mathrm{ml}$ spectrophotometrically.

Before inoculation 12 seedlings per entry were arranged in a randomized complete block design with four seedlings per plot and three replicates. Seedlings with six to eight true leaf pairs were inoculated artificially in nursery in August 1994 with a modified top-inoculation procedure based on the method of Wu and LIANG (1988b). Briefly, a small cotton ball was placed on each seedling around a cut made above the highest pair of true leaves, which were truncated with a clean blade, and then two drops of bacterium suspension were applied, following the wrapping of the cotton-covered top with tape. The environmental conditions were $70-80 \%$ in humidity, $28-32^{\circ} \mathrm{C}$ in day temperature and $24-28^{\circ} \mathrm{C}$ in night temperature.

Plant responses were assessed in 5, 10, 15, 20, 25, 30 and 35 days after inoculation. The symptom scores were recorded as: 0 , no symptom; 1 , no wilt symptom but top stained darkly; 2 , part of leaves wilted; and 3, dead. The scores were converted to bacterial wilt indices (BWI) following the simplified equation based on WINSTEAD and KELMAN (1952):

$$
D=X_{i} / 3
$$

where, $D$ is the disease index; $X_{i}$ the symptom score; and 3 the highest grade of symptom score.

\section{Field trial and trait measurement}

The field trial was planted at a site previously occupied by a plantation of an E. urophylla $\times$ grandis hybrid clone in Gaoyao County $\left(112^{\circ} 34^{\prime} \mathrm{E}\right.$ and $\left.23^{\circ} 01^{\prime} \mathrm{N}\right)$, Guangdong Province, China in April 1995, where more than half of the cuttings died of evident bacterial wilt symptoms by age five years. The site was cleared in blocks to retain the slightly infested patches. The field experimental design was same as nursery arrangement, namely, four-seedling row plot and three replicates. Seedlings that died during the nursery phase due to bacterial wilt infection were treated as missing.

Measurements were made in the five consecutive years after planting, and the traits measured were height $(\mathrm{H})$, diameter at breast height $(\mathrm{DBH})$ and wilt symptoms. The symptom scores were assessed using the subjective visual scores as used to assess symptoms in the nursery. The highest wilt symptom was recorded as the final performance and converted to a similar BWI as nursery manipulation. All trees that died during the observation years were excluded from analyses of $\mathrm{H}$ and $\mathrm{DBH}$.

\section{Statistical analyses}

The highest wilt symptom in both nursery and field investigations was recorded as the final performance and converted to BWI as described in the equation (1) above. For both growth traits $(\mathrm{H}$ and $\mathrm{DBH})$ and $\mathrm{BWI}$, the following linear model on individual basis was employed to estimate the genetic components of variance:

$$
Y_{i j k}=\mu+M_{i}+F_{j}+M F_{i j}+B_{k}+E_{i j k}
$$

where, $Y_{i j k}$ is the phenotypic value of the individual between the $i$ th male parent and the $j$ th female parent in the $k$ th replicate; $\mu$ an overall mean; $M_{i}$ the genetic effect of the $i$ th male parent; $F_{j}$ the genetic effect of the $j$ th female parent; $M F_{i j}$ the interaction effect between the $i$ th male and the $j$ th female; $B_{k}$ the effect of the $k$ th block (fixed); and $E_{i j k}$ the residual error. The analysis of variance (ANOVA) was performed using SAS Proc GLM SS1 and the variance components were estimated using SAS Proc VARCOMP method REML (SAS INSTITUTE, 1997). Standard errors of variance components were estimated according to BECKER (1984, p. 44-45).

Narrow-sense heritability based on all individual trees $\left(h^{2}\right)$ was estimated using the following formula:

$$
h^{2}=2\left(\sigma_{F}^{2}+\sigma_{M}^{2}\right) /\left(\sigma_{F}^{2}+\sigma_{M}^{2}+\sigma_{M F}^{2}+\sigma_{E}^{2}\right)
$$

assuming an inbreeding coefficient of zero between the parents. Standard errors of $h^{2}$ (approximation) were calculated according to BECKER (1984, p. 82-87).

Phenotypic correlation coefficients $\left(r_{p}\right)$ and genetic correlation coefficients $\left(r_{g}\right)$ between growth traits and BWI were estimated on plot mean basis by MINQUE (0/1) method (Zhu, 1992). Both phenotypic and genetic correlation analyses were conducted through computerized software QGA Station 1.0 (http://www.cab.zju.edu.cn/english/ics/faculty/zhujun.htm).

\section{Results}

Growth of the field trial was moderate at age five years as no tending and fertilization were applied after planting, totally averaging $12.16 \pm 2.71 \mathrm{~m}$ in $\mathrm{H}$ and $9.19 \pm 2.10 \mathrm{~cm}$ in $\mathrm{DBH}$. Mean performance varied slightly among factorials (Table 2). Factorial I demonstrated the best performance in survival and average growth traits ( $\mathrm{H}$ and $\mathrm{DBH})$ while Factorial III had the lowest BWI. Standard errors were relatively higher in BWI than growth traits for all the three factorials, suggesting a higher coefficient of variation in the disease susceptibility.

Variance components due to female, male and female $x$ male effects varied for the traits and factorials studied (Table 3). For both growth traits $\mathrm{H}$ and $\mathrm{DBH}$, female variance was statistically significant at $0.1,0.05$ or 0.01 level in factorials I and II while male and female $x$ male variances were both significant at $0.1,0.05$ or 0.01 level in factorials II and III. Thus, it appeared that female, male and female $x$ male effects had a significant role in $\mathrm{H}$ and $\mathrm{DBH}$. Also, the percentage explained by female, male or female $x$ male of the total variance varied with either trait or factorial. For example, female $x$ male vari-

Table 2. - Average performance of the field trial for different interspecific factorials by age five.

\begin{tabular}{lcccc}
\hline \multirow{2}{*}{ Mating design } & \multicolumn{4}{c}{ Average } \\
\cline { 2 - 5 } & Survival & $\mathrm{H}(\mathrm{m})$ & $\mathrm{DBH}(\mathrm{cm})$ & $\mathrm{BWI}$ \\
\hline Factorial I (E. urophylla $\times$ E. tereticornis) & $68.2 \%$ & $12.98 \pm 2.18$ & $9.60 \pm 2.09$ & $0.1437 \pm 0.1728$ \\
Factorial II (E. urophylla $\times$ E. camaldulensis) & $64.6 \%$ & $12.17 \pm 3.87$ & $8.96 \pm 2.52$ & $0.1561 \pm 0.1456$ \\
Factorial III (E. urophylla $\times$ E. exserta) & $66.7 \%$ & $11.57 \pm 2.16$ & $8.55 \pm 1.65$ & $0.1284 \pm 0.1193$ \\
\hline
\end{tabular}

Survival was calculated by taking into account of trees that died of both bacterial wilt and other reasons. 
Table 3. - Analysis of variance of the hybrid traits.

\begin{tabular}{lccccc}
\hline \multirow{2}{*}{ Source } & d.f. & \multicolumn{4}{c}{ Variance component for each trait (\%) } \\
\cline { 3 - 6 } & & $\mathrm{H}$ & DBH & BWI \\
\hline \multicolumn{2}{l}{ Factorial I (E. urophylla $\times$ E. tereticornis) } & & \\
Female & 2 & $0.8829 \pm 0.3321(12.3)^{*}$ & $0.9596 \pm 0.2869(14.9)^{* *}$ & $0.0 \pm 0.0(0.0)^{\mathrm{ns}}$ \\
Male & 4 & $0.3368 \pm 0.3066(4.7)^{\mathrm{ns}}$ & $0.2124 \pm 0.1320(3.3)^{\mathrm{ns}}$ & $0.0111 \pm 0.0020(19.0)^{* * *}$ \\
FemalexMale & 8 & $0.0 \pm 0.0(0.0)^{\mathrm{ns}}$ & $0.4351 \pm 0.3832(6.8)^{\mathrm{ns}}$ & $0.0126 \pm 0.0092(21.6)^{* * *}$ \\
Residual & 99 & $5.9764 \pm 0.5526(83.0)^{* * *}$ & $4.8234 \pm 0.5022(75.0)^{* * *}$ & $0.0347 \pm 0.0026(59.4)^{* * *}$
\end{tabular}

Factorial II (E. urophylla $\times$ E. camaldulensis)

$\begin{array}{lcccc}\text { Female } & 2 & 1.6419 \pm 0.2021(9.8) * & 1.2785 \pm 0.2120(14.0)^{* * *} & 0.0 \pm 0.0(0.0)^{\mathrm{ns}} \\ \text { Male } & 2 & 1.7348 \pm 0.1124(10.4) * & 1.9121 \pm 0.1354(20.9)^{* * *} & 0.0029 \pm 0.0032(5.6)^{*} \\ \text { FemalexMale } & 4 & 2.3029 \pm 1.2343(13.8) * & 1.0124 \pm 0.8876(11.1)^{* *} & 0.0 \pm 0.0(0.0)^{\mathrm{ns}} \\ \text { Residual } & 72 & 10.9997 \pm 0.9934(66.0)^{* * *} & 4.9469 \pm 0.3284(54.0)^{* * *} & 0.0490 \pm 0.0054(94.4)^{* * *}\end{array}$

Factorial III (E. urophylla $\times$ E. exserta)

\begin{tabular}{lcccc} 
Female & 2 & $0.2356 \pm 0.2544(2.3)^{\mathrm{ns}}$ & $0.4632 \pm 0.6023(5.7)^{\mathrm{ns}}$ & $0.0 \pm 0.0(0.0)^{\mathrm{ns}}$ \\
Male & 2 & $0.4814 \pm 0.2069(4.8)^{*}$ & $1.1883 \pm 1.1122(14.6)^{*}$ & $0.0052 \pm 0.0078(12.4)^{* *}$ \\
FemalexMale & 4 & $1.5586 \pm 1.4478(15.4)^{* *}$ & $1.6878 \pm 2.0461(20.8)^{* *}$ & $0.0 \pm 0.0(0.0)^{\mathrm{ns}}$ \\
Residual & 63 & $7.8208 \pm 0.8266(77.5)^{* * *}$ & $4.7895 \pm 0.6876(58.9)^{* * *}$ & $0.0366 \pm 0.0048(87.6)^{* * *}$ \\
\hline
\end{tabular}

$* * *$, ** and *: significant at $0.01,0.05$, and 0.1 levels, respectively; ns: non-significant at 0.1 level.

ance made up $20.8 \%$ in $\mathrm{DBH}$ of the total variance in Factorial III, whilst the ratios were $0.0 \%$ in $\mathrm{H}$ and $6.8 \%$ in $\mathrm{DBH}$ in Factorial I.

For the trait BWI, female variance was consistently zero, male variance was, on the contrary, significant at $0.1,0.05$ or 0.01 level over the three factorials, and female $x$ male interaction variance was significant only at 0.01 level in factorial I, which suggested both additive (male) and dominant (female $x$ male) effects were involved in the genetics of bacterial wilt susceptibility in eucalypts, and additive was the major.

The narrow-sense heritability $\left(h^{2}\right)$ estimates for the growth traits on individual basis ranged between $0.14 \pm 0.12$ and 0.70 \pm 0.09 over the three factorials (Table 4), suggesting that growth of the hybrids was under a low to high level of additive genetic control in all the factorials. The estimates of $h^{2}$ varied strongly with either trait or factorial. For instance, the heritability was found low for $\mathrm{H}$ in Factorial III $(0.14 \pm 0.12)$ while moderately high in factorials I and II $(0.34 \pm 0.18$ and $0.40 \pm$ 0.08 , respectively), and the trait DBH generally had the highest value of $h^{2}$ across all the factorials (0.36 $\left.\pm 0.12-0.70 \pm 0.09\right)$ (Table 4).

The $h^{2}$ estimates for BWI varied also with factorial (Table 4). Bacterial wilt susceptibility appeared to be a moderately inheritable trait in all three factorials $\left(h^{2}\right.$ ranging from $0.11 \pm 0.06$ to $0.38 \pm 0.17)$

Growth traits had low and non-significant correlations with BWI in both phenotypic and genetic terms for all three factorials $(-0.10 \pm 0.08-0.17 \pm 0.14)$, negative in factorials I and II, but positive in Factorial III (Table 5). Meanwhile, both phenotypic and genetic correlation coefficients between $\mathrm{H}$ and $\mathrm{DBH}$ were at 0.01 or 0.05 significance level (data not shown).
Table 4. - Individual-based narrow-sense heritability $\left(h^{2}\right)$ for each trait over the three factorials.

\begin{tabular}{lccc}
\hline \multirow{2}{*}{ Mating design } & \multicolumn{3}{c}{$h^{2}$} \\
\cline { 2 - 4 } & $\mathrm{H}$ & $\mathrm{DBH}$ & $\mathrm{BWI}$ \\
\hline Factorial I (E. urophylla $\times$ E. tereticornis) & $0.34 \pm 0.18$ & $0.36 \pm 0.12$ & $0.38 \pm 0.17$ \\
Factorial II (E. urophylla $\times$ E. camaldulensis) & $0.40 \pm 0.08$ & $0.70 \pm 0.09$ & $0.11 \pm 0.06$ \\
Factorial III (E. urophylla $\times$ E. exserta) & $0.14 \pm 0.12$ & $0.41 \pm 0.11$ & $0.25 \pm 0.10$ \\
\hline
\end{tabular}

Table 5. - Phenotypic and genetic correlations between growth traits ( $\mathrm{H}$ and $\mathrm{DBH})$ and BWI.

\begin{tabular}{|c|c|c|c|c|}
\hline \multirow{2}{*}{ Mating design } & \multicolumn{2}{|c|}{$r_{P}$ with BWI } & \multicolumn{2}{|c|}{$r_{g}$ with BWI } \\
\hline & $\mathrm{H}$ & DBH & $\mathrm{H}$ & DBH \\
\hline Factorial I (E. urophylla $\times$ E. tereticornis $)$ & $-0.03 \pm 0.07^{\mathrm{ns}}$ & $-0.01 \pm 0.08^{\text {ns }}$ & $-0.05 \pm 0.03^{\text {ns }}$ & $-0.01 \pm 0.05^{\mathrm{ns}}$ \\
\hline Factorial II (E. urophylla $\times$ E. camaldulensis) & $-0.09 \pm 0.14^{\mathrm{ns}}$ & $-0.05 \pm 0.13^{\text {ns }}$ & $-0.10 \pm 0.08^{\mathrm{ns}}$ & $-0.09 \pm 0.08^{\text {ns }}$ \\
\hline Factorial III $(E$. urophylla $\times$ E. exserta) & $0.15 \pm 0.13^{\mathrm{ns}}$ & $0.17 \pm 0.14^{\mathrm{ns}}$ & $0.11 \pm 0.09^{\mathrm{ns}}$ & $0.13 \pm 0.06^{\mathrm{ns}}$ \\
\hline
\end{tabular}

ns: non-significant at 0.1 level.

\section{Discussion}

Both bacterial wilt resistance and growth are traits of major economic significance for tropical and subtropical eucalypt plantations worldwide. In this study we have examined the genetic variation and evaluated the genetic parameters for these traits in Eucalyptus hybrids. Even though the results presented suffer to some extent from the limited number of parents employed in each of the interspecific factorials, they have nonetheless important implications for operational breeding of eucalypts.

Variance components due to female, male and female $\mathrm{x}$ male effects differ markedly between traits and factorials. Such variation is common in a number of previous reports, e.g. in eucalypts (Bouvet and Vigneron, 1996) and pines (DiETERS et al., 1997), and may be caused by the limited number of either male or female parents (PAUL et al., 1997; KUSNANDAR et al., 1998; IsIK et al., 2003) or progeny analysed for each mating design (GRIFFIN and CoTTERILL, 1988). In this experiment only three or five parents per sex, along with 12 sibs per cross, were tested for each factorial mating, and thus a larger number of parents would be preferable for each factorial in order to obtain more reliable genetic parameter estimates.

For each hybrid population in this study, the residual variances obtained in the analysis of variance were fairly large. These large residual variances could be due to substantial levels of non-additive genetic variance, environmental variation, error or combination of these factors. If a significant proportion of the residual variance was in fact due to non-additive genetic variance, there would be the possibility of exploiting this type of genetic effects via mass vegetative propagation of clones selected for superior growth and disease resistance ( $\mathrm{YU}$ et al., 2003).

The mode of inheritance of bacterial wilt resistance, or susceptibility, is still controversial in most plant species. The presence of a single dominant gene controlling resistance to bacterial wilt has been reported in tomato (TIKoO et al., 1983; MonMA and SAKATA, 1993), eggplant (CHAUdHARY and SHARMA, 1999) and Arabidopsis thaliana (Ho and YANG, 1999). However, YUAN et al. (1999) reported that the inheritance of resistance to bac- 
terial wilt (pathotype II) in sweet potato was controlled by multiple genes. The results reported here indicate that susceptibility to bacterial wilt, at least in the eucalypt hybrids examined, is related with both additive (male) and dominant (female $x$ male) genetic effects. This supports an "additive-dominant" model as proposed by FENG et al. (2003). Thus, both additive and non-additive gene actions appear to be important for bacterial wilt resistance in eucalypts, as has been reported for tomato by ANAND et al. (1993). Nonetheless, it is still appropriate to select parents with high general combining ability in terms of bacterial wilt resistance.

Though the individual-based narrow-sense heritability estimates obtained in this study for growth traits differed among the factorials, they were within the range of those reported previously in other eucalypt crosses except for one case where heritability of $0.70 \pm 0.09$ was estimated in $\mathrm{DBH}$ in Factorial II (see ElDRIDGE et al., 1993). For instance, HodGe et al. (1996) reported heritabilities of 0.04 to 0.23 for two-year-old volume over different intraspecific crosses between $E$. globulus and $E$. nitens, and BOUNET and VIGNERON (1995) reported heritabilities of 0.25 to 0.45 for 39-month-old growth traits $(\mathrm{H}, \mathrm{DBH}$ and $\mathrm{V})$ for $E$. urophylla $\times$ E. pellita crosses. The heritability obtained for DBH in Factorial II $(0.70 \pm 0.09)$ in our study was markedly higher than those published from other eucalypt work, which might be attributed to small family $x$ replication interaction and within-family variances in comparison with the family variances, regarding the small size of progeny studied.

It is common in forest trees for $h^{2}$ estimates of the same trait to vary among different populations and/or trial sites, especially when the number of parents tested is relatively small. For instance, BouvET and Vigneron (1995) found that heritability and its trend with age varied with mating design even in the same hybrid population of $E$. urophylla $\times$ E. pellita, and HODGE et al. (1996) found that heritability differed with site in the same control-pollinated population in E. globulus and $E$. nitens. Similarly, Dieters et al. (1997) found heritability estimates were substantially different between Pinus caribaea $\times P$. oocarpa and $P$. caribaea $\times P$. tecunumanii populations and between trial sites.

In current study growth traits show weak correlations with BWI in both phenotypic and genetic terms. The results obtained were generally in agreement with experiments conducted previously in other crops. For example, Monma and SAKATA (1992) found no correlation between bacterial wilt resistance and fruit weight in tomato. This indicates that it may be possible to select superior trees with both fast growth and high resistance to bacterial wilt in eucalypt hybrid populations in operational breeding programs.

\section{Acknowledgments}

This work was supported by the Guangdong Natural Science Foundation, China (grant no. 011386). We thank Dr. HARRY Wu and Dr. ROGER ARNOLD for their critical comments on an early version of this manuscript and Professor JUN ZHU for his kind provision of software QGA Station 1.0. We also thank WeNYou GAN and RUIGUANG QIAN for their cooperation in field trial maintenance as well as YUEHUA CHAO for her assistance in bacterial inoculum preparation. We appreciate the help of JIANMIN XU and Hong LI in field measurement.

\section{References}

Anand, N., Sadashiva, A. T., Tikoo, S. K., Ramkishun and REDDY, K. M. (1993): Resistance to bacterial wilt in tomato: gene dosage effects. In: Bacterial wilt. ACIAR proceedings No. 45. Edited by Hartman, G. L. and Hayward, A. C. pp. 142-148.
Araúso, J. A., Sousa, R., Lemos, L. and Borralho, N. M. G. (1996): Estimates of genetic parameters and prediction of breeding values for growth in Eucalyptus globulus combining clonal and full-sib progeny information. Silvae Genet. 45: $223-226$.

BECKER, W. A. (1984): Manual of Quantitative Genetics. Ed. 4. Academic Enterprises, Pullman, WA. 188p.

BouveT, J. M. and Vigneron, P. (1995): Age trends in variances and heritabilities in Eucalyptus factorial mating designs. Silvae Genet. 44: 206-216.

Bouvet, J. M. and Vigneron, P. (1996): Variance structure in Eucalyptus hybrid populations. Silvae Genet. 45: 171-177.

BUDDENHAGEN, I. (1964): Biological and physiological aspects of bacterial wilt caused by Pseudomonas solanacearum. Ann. Rev. Phytopathol. 2: 203-230.

Cнао, J. (1982): A preliminary investigation of bacterial wilt occurrence in Eucalyptus saligna and E. grandis plantations in Guangxi Province, China (in Chinese). Guangxi For. Information (4): 30-31.

Chaudhary, D. R. and Sharma, D. K. (1999): Studies on bacterial wilt (Pseudomonas solanacearum E. F. Smith) resistance in Brinjal. Indian J. Hill Farming 12: 94-96.

Coutinho, T. A., Roux, J., Riedel, K-H., Terblanche, J. and WingFieLD, M. J. (2000): First report of bacterial wilt caused by Ralstonia solanacearum on eucalypts in South Africa. European J. For. Pathol. 30: 205-210.

Dianese, J. C., Dristig, M. C. and CruZ, A. P. (1990): Susceptibility to wilt associated with Pseudomonas solanacearum among six species of Eucalyptus growing in equatorial Brazil. Aust. Plant Pathol. 19: 71-76.

Dieters, M. J., Nikles, D. G., Toon, P. G. and Pomroy, P. (1997): Genetic parameters for $F_{1}$ hybrids of Pinus caribaea var. hondurensis with both Pinus ocarpa and Pinus tecunumanii. Can. J. For. Res. 27: 1024-1031.

EldRIDGe, K., Davidson, J., HaRWood, C. and van WyK, G. (1993): Eucalypt Domestication and Breeding. Oxford: Oxford University Press, 288p.

FENG, L., QU, D., JIN, L. and LIAN, Y. (2003): Genetic analysis of resistance to bacterial wilt (Ralastonia solanacearum) in eggplant (Solanum melongena L.) (in Chinese). Acta Horti. Sinica 30: 163-166.

GAN, S., BAI, J., WU, K., WU, J. and Xu, J. (1998): Seedling resistance of interspecific crosses from female Eucalyptus urophylla to bacterial wilt (in Chinese). For. Res. 11: 569-573.

Grevaves, B. L., Borralho, N. M. G., Raymond, C. A., Evans, R. and Whiteman, PH. (1997): Age-age correlations in and relationships between basic density and growth in Eucalyptus nitens. Silvae Genet. 46: 264-270.

Griffin, A. R. and CotTerill P. P. (1988): Genetic variation in growth of out-crossed, selfed and open-pollinated progenies of Eucalyptus regnans and some implications for breeding strategy. Silvae Genet. 37: 124-131.

HARDNER, C. M. and PotTs, B. M. (1995): Inbreeding depression and changes in variation after selfing in Eucalyptus globulus ssp. globulus. Silvae Genet. 44: 46-54.

Ho, G. and YANG, C. (1999): A single locus leads to resistance of Arabidopsis thaliana to bacterial wilt caused by Ralstonia solanacearum through a hypersensitive-like response. Phytopathology 89: 673-678.

Hodge, G. R., Volker, P. W., Potts, B. M. and Owen, J. V. (1996): A comparison of genetic information from open-pollinated and control-pollinated progeny tests in two eucalypt species. Theor. Appl. Genet. 92: 53-63.

IsIK, F., LI, B. and Frampton, J. (2003): Estimates of additive, dominance and epistatic genetic variances from a clonally replicated test of loblolly pine. For. Sci. 49: 77-87.

Jones, T. H., Potts, B. M., Vaillancourt, R. E. and Davies, N. W. (2002): Genetic resistance of Eucalyptus globulus to autumn gum moth defoliation and the role of cuticular waxes. Can. J. For. Res. 32: 1961-1969.

Jordan, G. J., Potts, B. M. and Clarke, A. R. (2002): Susceptibility of Eucalyptus globulus ssp. globulus to sawfly (Perga affinis ssp. insularis) attack and its potential impact on plantation productivity. For. Ecol. Manage. 160: 189-199. 
Kelman, A. (1954): The relationship of pathogenicity in Pseudomonas solanacearum to colony appearance on a tetrazolium medium. Phytopathology 44: 693-695.

Kusnandar, D., Galwey, N. W., Hertzler, G. L. and Butcher, T. B. (1998): Age trends in variances and heritabilities for diameter and height in maritime pine (Pinus pinanster Ait.) in Western Australia. Silvae Genet. 47: 136-141.

Lopez, G. A., Potts, B. M., Vaillancourt, R. E. and Apiolaza, L. A. (2003): Maternal and carryover effects on early growth of Eucalyptus globulus. Can. J. For. Res. 33: 2108-2115.

MONMA, S. and SAKATA, Y. (1993): Inheritance of resistance to bacterial wilt in tomato. In: Bacterial Wilt. ACIAR proceedings No. 45. Edited by Hartman, G. L. and Hayward, A. C. pp. $149-153$.

OsoRio, L. F., White, T. L. and Huber, D. A. (2001): Age trends of heritabilities and genotype-by-environment interactions for growth traits and wood density from clonal trials of Eucalyptus grandis Hill ex Maiden. Silvae Genet. 50: 30-37.

Paul, A. D., Foster, G. S., Caldwell, T. and McRae, J. (1997): Trends in genetic and environmental parameters for height, diameter, and volume in a multilocation clonal study with loblolly pine. For. Sci. 43: 87-98.

Roux, J., Coutinho, T. A., Byabashaija, D. M. and Wingfield, M. J. (2001): Diseases of plantation Eucalyptus in Uganda. South Afri. J. Sci. 97: 16-18.

SAS Institute Inc. (1997): SAS/STAT ${ }^{\circledR}$ user's guide. Version 6.0, 4th ed. SAS Institute Inc., Cary, N.C.

SATHYANARAYANA, H. V. and ANAND, N. (1993): Developing bacterial wilt resistant $\mathrm{F}_{1}$ hybrids for processing in tomato (Lycopersicon exculentum). In: Bacterial Wilt. ACIAR proceedings No. 45. Edited by Hartman, G. L. and Hayward, A. C. pp. $158-162$.

SorIA, F. and BorralHo, N. M. G. (1997): The genetics of resistance to Phoracantha semipunctata attack in Eucalyptus globulus in Spain. Silvae Genet. 46: 365-369.

Sudo, S., Oliveira, G. H. N. and Pereira, A. C. (1983): Eucalipto (Eucalyptus spp.), bracaatinga (Mimosa scrabella Penth.) novas hospedeiras de Pseudomonas solanacearum E. F. Smith. Fitopatologia Brasileira 8: 631.

Tikoo, S. K., ANAN, N. and RAMKRISHNA (1983): Presence of two independent genetic systems for resistance to bacterial wilt (Pseudomonas solanacearum) in tomato. In: Proceedings of the $15^{\text {th }}$ International Genetic Congress, 12-23 December 1983, New Delhi, India.

Wei, X. and Borralho, N. M. G. (1998): Genetic control of growth traits of Eucalyptus urophylla S. T. Blake in southeast China. Silvae Genet. 47: 158-165.

Winstead, N. N. and Kelman, A. (1952): Inoculation techniques for evaluating resistance to Pseudomonas solanacearum. Phytophthology 42: 628-634.

Wu, Q. and LIANG, Z. (1988a): Selection of species and provenances of Eucalyptus for resistance to bacterial wilt (in Chinese). J. South China Agri. Univ. 9: 41-45.

WU, Q. and LIANG, Z. (1988b): Identification and pathogenic tests of the causal organism of the bacterial wilt of Eucalyptus (in Chinese). J. South China Agri. Univ. 9: 59-67.

YabuUchi, E., Kosako, Y., Yano, I., Hotta, H. and Nishiuchi, Y. (1995): Transfer of two Burkholderia and an Alcaligenes species to Ralstonia gen. Nov.: Proposal of Ralstonia pickettii (RAlston, PAlleroni and Doudoroff, 1973) comb. Nov., Ralstonia solanacearum (SмITH, 1896) comb. Nov. and Ralstonia eutropha (DAvIS, 1969) comb. Nov. Microbiol. Immunol. 39 897-904.

Yu, Q., Yang, D-Q., Zhang, S. Y., Beaulieu, J. and Duchesne, I. (2003): Genetic variation in decay resistance and its correlation to wood density and growth in white spruce. Can. J. For. Res. 33: 2177-2183.

YuAN, Z., Chen, F., CHEN, X. and FANG, S. (1999): Inheritance of bacterial wilt resistance and its correlation with yield traits in sweet potato (in Chinese). J. Fujian Agri. Univ. 28: 413-416.

ZHU, J. (1992): Mixed model approaches for estimating genetic variances and covariance. J. Biomath. 7: 1-11.

\title{
Patterns of Pollen Flow and Genetic Differentiation Among Pollen Pools in Quercus salicina in a Warm Temperate Old-growth Evergreen Broad-leaved Forest
}

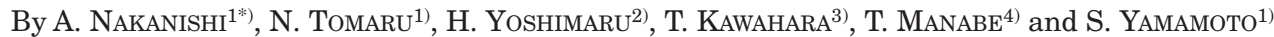

Forest Ecology and Physiology, Graduate School of Bioagricultural Sciences, Nagoya University, Nagoya 464-8601, Japan

(Received $5^{\text {th }}$ November 2004)

\begin{abstract}
Paternity analysis and analysis of molecular variance were used to determine patterns of pollen flow and genetic differen-

\footnotetext{
1) Laboratory of Forest Ecology and Physiology, Graduate School of Bioagricultural Sciences, Nagoya University, Nagoya 464-8601, Japan.

2) Ecological Genetic Laboratory, Department of Forest Genetics, Forestry and Forest Products Research Institute, Tsukuba, Ibaraki 305-8687, Japan.

3) Forest Dynamics and Diversity Group, Hokkaido Research Center, Forestry and Forest Products Research Institute, Hitsujigaoka-7, Toyohira, Sapporo, Hokkaido 062-8516, Japan.

$\left.{ }^{4}\right)$ Kitakyushu Museum of Natural History and Human History, Kitakyushu 805-0071, Japan.

*) Corresponding author: ATSUshi NAKANishi, E-mail: tomaru@agr.
} nagoya-u.ac.jp tiation among pollen pools in Quercus salicina in an 11.56-ha plot in a temperate old-growth evergreen broad-leaved forest. The genotypes at seven microsatellite loci were determined for 111 adult trees and 276 seeds collected from under eight seed parents. The proportion of pollen flow from outside the plot (further than $100 \mathrm{~m}$ ) was $52.2 \%$, indicating that long-distance pollen flow occurred frequently in this species, as observed in other Quercus species. The pollen pools from inside and outside the plot differed genetically, and genetic structure was detected in the population of adult trees within the plot. Therefore, longdistance pollen flow from outside the plot may introduce new or low-frequent alleles, and increase genetic diversity in this population. However, the actual average distance of pollen flow within the plot was significantly shorter than the average potential distance, and negative exponential curves explained well the frequencies of matings as functions of the distance 